\title{
Editorial
}

\section{A New ILA Congress: Towards a New Reality}

\section{Un nuevo congreso del ILA: hacia una nueva realidad}

\author{
Ricardo Kaempf ${ }^{1}$ (1) Raimundo Araújo Filho ${ }^{2(0)}$ Pedro J. Delgado $3,4(0)$ \\ ${ }^{1}$ Hand Surgeon, Santa Casa de Misericórdia de Porto Alegre, Porto \\ Alegre, Rio Grande do Sul, Brazil \\ 2 Hand and Upper Limb Surgeon, Maceió, Alagoas, Brazil \\ ${ }^{3}$ Hospital Universitario HM Monteprincipe, Madrid, Spain \\ ${ }^{4}$ Universidad CEU San Pablo, Orthopaedics Department, Boadilla del \\ Monte, Madrid, Spain
}

Rev Iberam Cir Mano 2021;49:1-3.

The people of Latin America have been sharing common values through history, language and costumes, along with the passionate way of facing, celebrating, or surviving hardships. Passion and solidarity are a constant in solving financial, professional or family problems.

Founded in 1993 during the congress of Sociedad Española de Cirugía de Mano (Spanish Society of Hand Surgery, SECMA, in Spanish), the Ibero-American Hand Surgery Group (Grupo Ibero Latinoamericano de Cirugía de la Mano, ILA, in Spanish; - Fig. 1) carries along that peculiar DNA. The group emerged from the union and the passion of four hand surgery pioneers. Doctors Carlos Irisarri (Spain); Walter Albertoni (Brazil); Eduardo Zancolli (Argentina); and Luis Scheker (United States) realized that hand surgery specialists from the Ibero-Latin-American region were in need of more room and visibility in large, international congresses. They also felt the need for a lighter and more pleasant learning within an environment of camaraderie and friendship for an enhanced exchange of ideas and experiences. And, also, with a milder teacher-student hierarchy.

Since then, the ILA Group has aimed to spread and develop the work of Latin-American hand surgery specialists, aggregating and enriching the work of local societies without any conflict or competition. Moreover, the ILA prioritizes the merit of scientific production. Those who research and publish will have a special place.

The choice of ILA venues is based on local organizing committee, but also on the need to develop hand surgery in certain locations. During the past 28 years, 12 different ILA congresses have taken place in several countries:
I - 1998: Playa Bávaro, Dominican Republic. President: Dr. Marcos Nuñez;

II - 1999: São Paulo, Brazil. President: Dr. Walter Albertoni;

III - 2000: Cancún, Mexico. President: Dr. Alejandro Espinosa;

IV - 2001: Seville, Spain. President: Dr. Pilar Pradilla;

V - 2002: Florence, Italy. President: Dr. Massimo Ceruso; VI - 2005: Joinville, Brazil. President: Dr. Valdir Steglich; VII - 2007: Zaragoza, Spain. President: Dr. García Julve;

VIII - 2007: Buenos Aires, Argentina. President: Dr. Miguel Capomassi;

IX - 2008: Oporto, Portugal. President: Dr. Cesar Silva;

X - 2009: Cartagena, Colombia. President: Dr. Francisco Camacho;

XI - 2017: Guanacaste, Costa Rica. President: Dr. Cristhian Castro; and

XII - 2018: Riviera Maya, Mexico. President, Dr. Juan Bonfil.

Since then, the ILA group has evolved from just a gathering of friends to a very organized group that includes a body of directors and commissions. The last two congresses (Costa Rica, 2018, and Mexico, 2019) have taken place as an independent event without the need to rely on any other local or national meeting, thus exhibiting the strength and growth of the ILA group, as shown by the 133 participants in Costa Rica and 174 participants in Mexico (-Fig. 2).

The XIII ILA Congress was supposed to take place in Northeastern Brazil, in the city of Maceió, in 2019. For

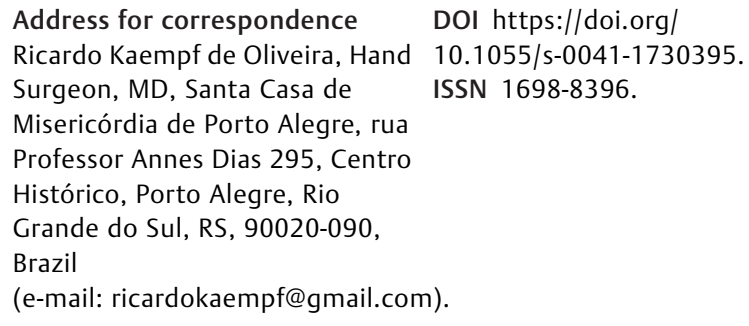

(c) 2021. SECMA Foundation. All rights reserved.

This is an open access article published by Thieme under the terms of the Creative Commons Attribution-NonDerivative-NonCommercial-License, permitting copying and reproduction so long as the original work is given appropriate credit. Contents may not be used for commercial purposes, or adapted, remixed, transformed or built upon. (https://creativecommons.org/ licenses/by-nc-nd/4.0/)

Thieme Revinter Publicações Ltda., Rua do Matoso 170, Rio de Janeiro, RJ, CEP 20270-135, Brazil 


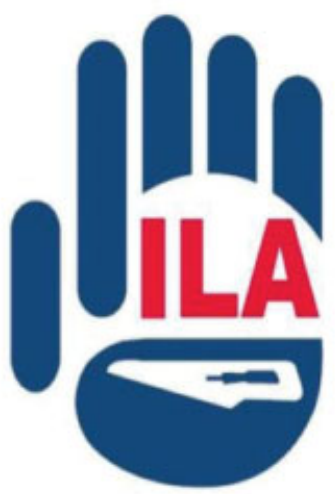

\section{Grupo ILA}

\section{Ibero Latinoamericano de Cirugía de la Mano}

Fig. 1 ILA Group logo.

more than one year, we made arrangements and publicized the congress, which was intended to be the largest in ILA history. We had more than 300 enrollments in advance by colleagues from 16 different countries, who would enjoy 3 exciting days filled with theoretical and practical lectures along with great support and interaction with the industry. Furthermore, during the 2019 IFSSH Congress, in Berlin, the
ILA group had the idea to invite for the first time ever a country outside our region. Italy was chosen, and Dr. Andrea Atzei acted as an "ambassador." There were meetings between Società Italiana di Chirurgia della Mano (Italian Society of Hand Surgery, SICM, in Italian) with the presence of its president, Dr. Bruno Batiston, and the board of directors of the 2020 ILA Congress (Dr. Ricardo Kaempf, President of the 2020 ILA Congress; Dr. Raimundo Araújo Filho, Co-president of 2020 ILA Congress; Dr. Pedro J. Delgado, ILA General Secretary for 2018-19; Dr. Carlos Irisarri, ILA founding member; Dr. Samuel Ribak, ILA General Secretary for 2020-21; Dr. Juan Bonfil, President of the 2018 ILA Congress). More than twenty Italian specialists were also expected in Brazil.

And then, by the end of February 2020, an unstable world started to face the terrible Covid-19 pandemic. The excitement-filled environment was replaced by apprehension, and, less than 30 days before the congress, we had to make the hard decision to postpone our dream. Our congress was the first to be postponed in Brazil. At that moment, we were sure that the participants' safety was the most important issue, regardless of the consequences and financial losses.

More than one year has gone by, and, after two postponements, the XIII ILA Congress has been scheduled for August 25th to 28th, 2021, at the same venue and with a
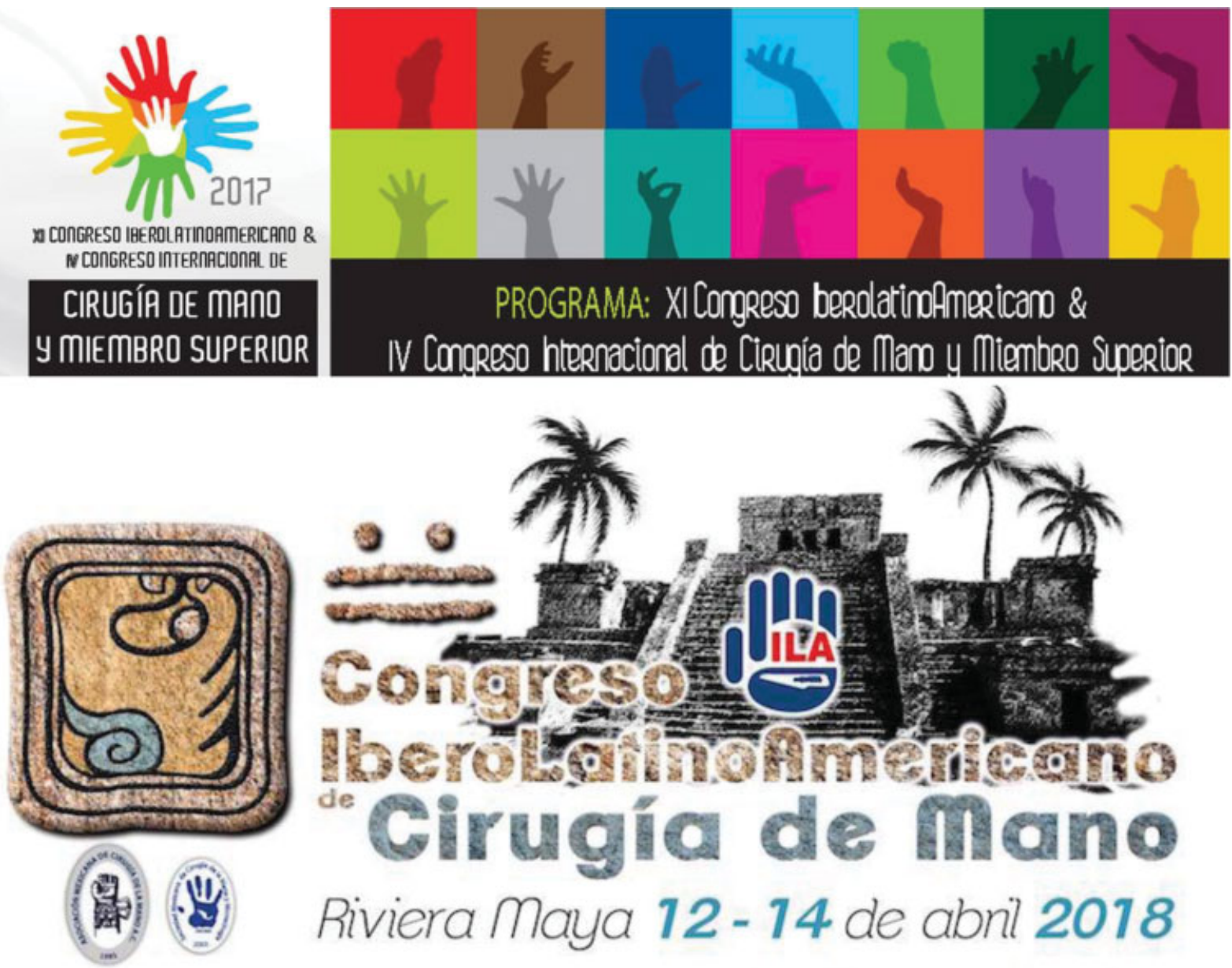

Fig. 2 ILA Group past Congresses folders. 


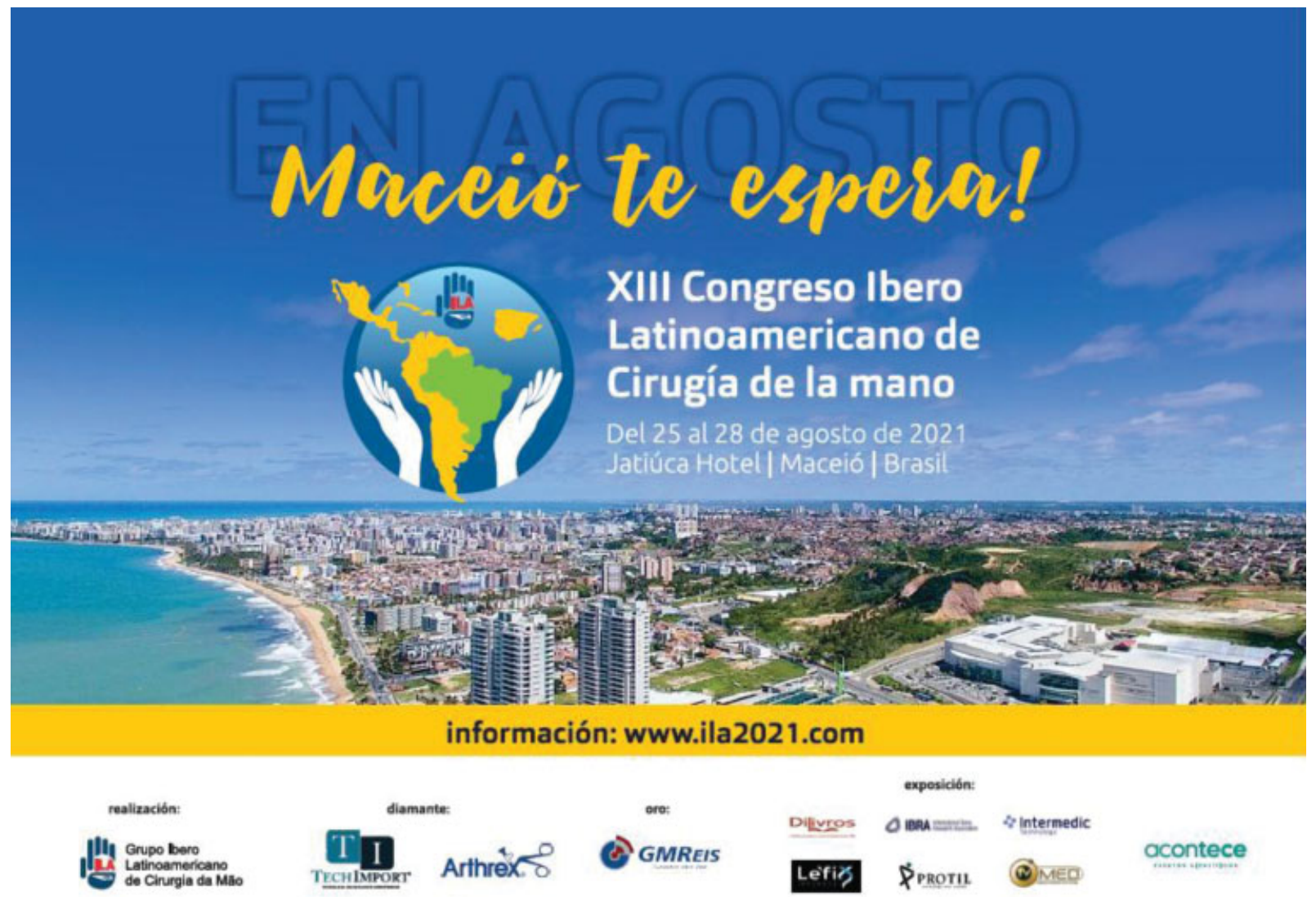

Fig. 3 ILA Group 2021 Congress to be hosted in Maceió, Brazil.

similar structure (-Fig. 3). We have been able to secure most contracts, budgets, and several other issues that involve financial resources with the smallest possible impact on the organization. Local, national and international health organisms do indicate that the current situation has improved, a good number of people are expected to have been vaccinated by the end of the first half of 2021, and, as such, all scientific events are to be adjourned to the second semester. Having that in mind, an adequate environment for updates and to celebrate should be provided.

We are aware of the hurdle and responsibility of holding a scientific event at the current stage. We have been having weekly meetings with the organization and local suppliers at Maceió so that we can provide a proper and safe structure. The ILA is ready.We want to safely welcome all colleagues, their families, our partners and collaborators involved in making this a great event. Therefore, we ask for your patience and understanding, as sometimes rules change over the course of one week.

We understand that preventive measures are key right now; yet, we are convinced that the world should not come to a halt. At the same time that science and technology have brought us several vaccines against Covid- 19 with overwhelming speed, hand surgery also needs to continue its development as a medical specialty.

We are aware of the fact that some colleagues from Europe or even from other countries in the Americas may face some obstacles to travel to Brazil. Flight restrictions and border barriers may still be in place, not to mention key personal issues. For that reason, we are adjusting things so that the ILA can be a mixed meeting, mostly composed of in-person participants, but also providing an online transmission to favor those who cannot be present.

The people from Brazil's Northeastern region have long been known as affectionate and warm hosts. And this mindset is the pillar of an unforgettable ILA Congress. The website of the congress (www.ILA2021.com) has been updated with all of the information and contacts so that every colleague can enjoy the 2021 ILA Congress in their own way.

We look forward to meeting you in Maceió in August! 